\title{
The Analysis and Strategy on Final Project Completion (TA) by Midwifery Students of Health Polytechnic of Malang
}

\author{
Afnani Toyibah* \\ * Midwifery Department, Health Polytechnic of Malang, Republic of Indonesia
}

\begin{abstract}
Midwifery students are required to become competent in conducting midwifery-related research, but all is not what it seems. More than 25\% of midwifery students of Health Polytechnic of Malang have been found to encounter untimely completion of their final project according to the stipulated duration. This study was therefore carried out with the view to finding out the process and the strategy of completing the final project on the regulated time. As a qualitative descriptive study, this research collected the data from in-depth interviews, documentation and observation. Final project supervisors, lecturers of Research Methodology Class, sixth semester students, alumni, and Academic Coordinator of the Midwifery Diploma Program of Health Polytechnic of Malang were chosen as the participants. The data obtained were then analyzed using descriptive analysis by Miles and Huberman and SWOT analysis. The results show that the administration of Research Methodology Class was already well planned, but its implementation has not positively influential to students' final project writing. Moreover, no formal supervision schedule for supervisors and students to follow was associated with the completion delay of the students' final project. Therefore, to help students to have good quality and on time completion of the final project, it is recommended that the students should be gradually mentored and the Research Methodology Course should expose students with ample of writing practices. The last but not least, the supervision schedule should be set from the outset for students and supervisor to obey.
\end{abstract}

Keywords: Analysis, Strategy, Final Project Completion (TA)

\section{Introduction}

The graduates of midwifery diploma program are obliged to be able to face any challenge of today's globalization. As stated in the vision of the Health Polytechnic of Malang, students of midwifery diploma program must possess competent and competitive midwifery skills. For that reason, they have to occupy themselves with high skills of midwifery care. In addition to the midwifery skills, they have to develop their skill of conducting a research as well. To achieve those objectives, at the end of their study they are required to conduct a research for their final project as the partial requirement to get their professional degree.

The curriculum of midwifery diploma program clearly state that the students are prepared to be competent and competitive health workers as well as researchers in the related field. To equipped students to work on this program, the Research Methodology Course ( 2 credits) is offered to students at fifth semester to deepen their understanding of a scientific paper prior to their Final Project ( 3 credits) in sixth semester. The subject covers the theoretical framework of a research especially in midwifery context. In this case the students need have a concrete practice to get into the nature of researching. The research practice will shape learner's attitudes, skills, teamwork, and creativity in conducting a research. Therefore, the students should be properly trained in research methods as well as enforced to show deep interests towards their research work.

However, the impact of this course on students' mastery of conducting a research did not positively influence their work on the final project writing. From the interviews with 10 students about their preparedness for their final projects, the result showed that all of them felt anxiety with various reasons. The dramatic effect was only $25 \%$ of students registered to have proposal exam on the stipulated duration, whereas, the rest of them retreated. The further impact would be the completion delay of the final project. At the end not all students would be able to graduate on time due to their unfinished papers.

As a technical implementation unit, midwifery department has developed some programs on the learning systems to improve the teaching learning, supervision, and service to students as recommended in the policy of the Department of Health. In order to attain those purposes, it is essential that the research on the variables attributed to delay in final project completion in the Midwifery Diploma Program of Health Polytechnic of Malang be conducted.

\section{Problem Questions}

The research question that guided the study is "What are attributive variables to students delay in completion of final project in Midwifery Diploma Program of Health Polytechnic of Malang?" In order to get in-depth study, the research question is then divided into two main focuses namely:

(1) What are attributive variables to students delay in completion of final project in Midwifery Diploma 
The Analysis and Strategy on Final Project Completion (TA) by Midwifery Students of Health ..

Program of Health Polytechnic of Malang? To obtain the data, the in-depth interview was employed to answer the following questions; (a) how is the implementation of the curriculum of Midwifery Diploma Program of Health Polytechnic of Malang related to the final project writing? (b) how do supervisors administer the supervision process? (c) to what extent do the students master the skill in conduct of research?

(2) What is the strategy to overcome the completion delay of students' final project in Midwifery Diploma Program of Health Polytechnic of Malang? To obtain the data, the in-depth interview was employed to answer the following questions (a) what strategy is applied in curriculum implementation related to the final project writing in Midwifery Diploma Program of Health Polytechnic of Malang, (b) what strategy is used by the supervisors in assisting students working with their final projects?, (c) what strategy is used to build the students' skill in conduct of research?

\section{Research Objectives}

The objectives of this study are:

(1) To describe the attributive variables to completion delay of students' final project in Midwifery Diploma Program of Health Polytechnic of Malang which include:

(a) to describe the implementation of the curriculum in Midwifery Diploma Program of Health Polytechnic of Malang related to the final project writing,

(b) to describe the process of supervision given by the supervisor and

(c) to describe the students' skill in conduct of research.

(2) To describe strategies to overcome completion delay of students' final project in Midwifery Department of Health Polytechnic of Malang which include:

(a) to describe the implementation strategy of the curriculum in Midwifery Diploma Program of Health Polytechnic of Malang related to the final project writing,

(b) to describe the supervision strategy

(c) to describe the students' ability to prepare the strategy in conduct of research.

The conceptual framework of research

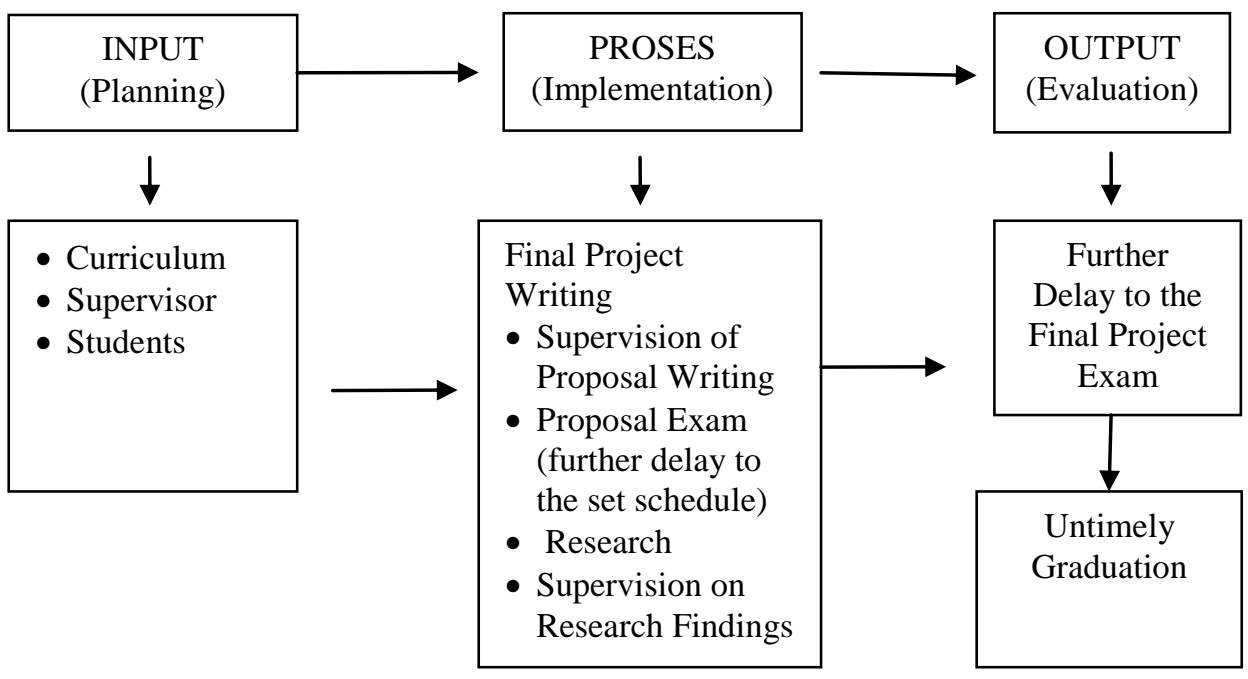

Figure (1) Conceptual Framework of the Research

\section{Methods}

\section{Research Approach and Design}

This study adopted a qualitative case study design. A case study is intended to study in-depth of a particular person, group, situation, and or position taken from the real life.

\section{Research Analysis Unit}

The research subject may be an individual, group, institution or community. Further Bodgan and Bilken (1992), asserts that the case studies have a descriptive tendency. In a descriptive study the collection of data is to provide an overview or affirmation of a concept, and to answer questions regarding the status of research subjects. This research depicted the completion strategy of students in the sixth semester of Midwifery Diploma Program of Health Polytechnic of Malang in an attempt to complete the final project writing at the regulated time. 
The Analysis and Strategy on Final Project Completion (TA) by Midwifery Students of Health ..

\section{Research Site}

The research site was at Midwifery Diploma Program Health Polytechnic of Malang located at Jalan Simpang 37 Ijen Malang. The primary reason was that Midwifery Diploma Program was a higher vocational education that required its students to conduct a research as their final project.

\section{Research Participants}

The participants of this study were particular figures in Midwifery Diploma Program of Health Polytechnic of Malang who could provide factual information about the final project writing. Those who met the specified characteristics consisted of (a) supervisor of final project, (b) coordinator of academic affairs, (c) VI semester students taking their final project, (d) lecturers of Research Methodology Course, and (e) alumni. The type of sampling used in this study was snowball sampling. Considered as the most important figure providing the key data, the coordinator of academic affairs was the first to be interviewed, and followed respectively by students of sixth semester, supervisors of final project, lecturer of Research Methodology Course, and alumni. When the information started to get saturated then the interview was terminated. At the end of the study 11 people were recorded to be the total number of participants.

\section{Data Collection Methods and Analysis}

Data collection methods in this study included (1) participatory observation (2) documentation and (3) In-depth interviews. The research procedures covered (1) preparation and (2) implementation conducted in three stages, namely: (a) Stage orientation, (b) exploratory phase, (c) focused research phase. To ensure the validity of the acquired data, the criteria involved: credibility, transferability, and conformability. To identify the necessary aspects to optimize to the process of final report writing, content analysis technique was administered. It required the researcher to understand detail content of the research area to assure the data obtained were sufficient to answer the research questions. The analysis used descriptive data analysis by Miles and Huberman (1992).

\section{Research Findings}

Located at Jl. Simpang Ijen no. 37 Malang, Midwifery Diploma Program Health Polytechnic of Malang has a wide span of $7522 \mathrm{~m}^{2}$ and a building area of $2572 \mathrm{~m}^{2}$ including 7 teaching learning rooms, an obstetric lab, a family planning lab, a pediatric lab, and a basic healthcare lab. Other carrying facilities are prayer room, gymnasium, sport center, and the best of all student dormitories with a land area of $7506 \mathrm{~m}^{2}$ and a building area of $4950 \mathrm{~m}^{2}$. The faculty members consists of 24 full-time lecturers, 20 of whom have taken their master education (S2), two undergraduate background (S1), and two diploma 4 background (D4). There are 7 administrative personnel ranging from elementary to undergraduate background. About 100 students are attending their third year which means all of whom should undergo their final project. For the purpose of assisting students with their final project writing, two supervisors are assigned which means the ratio of lecturers and students is $1: 10$.

Some findings in this study featured the interrelated variables in the following areas:

\section{(a) Implementation of the curriculum related to the final project writing}

The findings showed that (1) Research Methodology (3 credits) is offered in semester V, (2) syllabus and lesson plans were well-prepared, (3) learning schedule, academic calendar, and curriculum are formally set, (4) the teaching method was conducted in the form of lecturing, question and answer, discussion, and practice of drafting a proposal, (5) the lecture was stressed more on theories of researching than practice on writing a proposal, (6) according to the students the material was not enough to prepare them to write their final project when it deals with chapters to chapter writing, (7) students were well equipped with the knowledge of writing a scientific paper, but due to the lack of practice, they easily encountered problems, (8) at the end of the course students had to submit a research proposal, (9) the final project which is worth 3 credits and offered at semester VI, but in reality the students had to submit their title as well as the proposal of the final project in the fifth semester, (10) not all students could accomplish their proposals in the fifth semester causing the delay in the exam proposal, (11) the handbook of final project writing is prepared by Research Methodology team, (12) there was no timetable of supervision schedule, but rather it was an agreement between the supervisor and the student. Furthermore it depends on the availability of supervisors' time and students' motivation.

\section{(b) The process of final project supervision}

The findings reveal that (1) no fixed supervision schedule was set attributed to the untimely progress of completion; (2) supervision schedule relied upon the flexibility of students and supervisor. Those who intensively got going on the final project would have more frequency of supervision than those of the slow ones or the unmotivated ones, (3) the final project delay was associated with the disagreement of topics among the 
The Analysis and Strategy on Final Project Completion (TA) by Midwifery Students of Health ..

involved parties like supervisors, advisory committee, supervisor, or the student, (4) the length of supervision varies from 20 to 30 minutes depending on the amount of correction, (5) the appointed supervisors were skilled ones with regard to their educational background, (6) having trouble understanding the supervisor's feedback, students asked for further assistance, browsed internet, or asked friends' help, (7) the students often felt bored waiting for the supervisor due to waiting their turn of supervision, (8) supervision was conducted through face to face discussion based to enable students' deeper understanding on what they were writing.

\section{(c) The students' skill in conduct of research}

The findings indicate that (1) students' prior knowledge was very limited, (2) after attending the research class the students got improved knowledge in conduct of research, but in terms of identifying the problems of their research they still found themselves having difficulties, (3) determining the research problem of their final project was still decided through spontaneous thought which should from real phenomenon instead, (4) the ability of students varied greatly, but a high number of students considered themselves still lack of research knowledge, (5) in terms of practice students claimed that they need to practice chapter to chapter writing.

It is in line with the statement of lecturer of Research Methodology who stated that:

"The Research Methodology Class was taught in team (2 lecturers) and quite often we stayed in class together at the same time to get synergistic cooperation in materials and teaching methods. The schedule, the academic calendar and curriculum were well-prepared. The class was administered through discussion, lecturing, and practice on writing research proposals. A complete syllabus and lesson plans were all set (Lecturer D, 9 September 2012). In addition the Academic Coordinator of Midwifery Diploma Program stated that: "the Research Methodology Class was placed in the appropriate time at semester VI which is worth 3 credits. The final project committee decided that the proposal must be put in the fifth semester; the committee decided the supervisors based on their expertise and the students' interest of the final project topics. According to the academic calendar proposing the title of the final project should be due in October of the fifth semester, and the proposals should be completed in the fifth semester and in the first week of sixth semester the proposals exam should have been conducted ". (Lecturer E, 20 September 2012). Furthermore the student participant said that:"In writing the final project the students were given the final project handbook". (Students I, July 24, 2012). Meanwhile an Alumnus named A sayid that:"the handbook contains examples but unfortunately most of them were out of the midwifery contexts (Alumni A, August 9, 2012). The documentation findings obtained from the lecturers were subject syllabi, lesson plans, and final project handbook, and student list, but there were no record of proposal and supervision schedule.

There was no specific supervision schedule which was associated with the untimely completion of final project. The supervision schedule was flexible depending on the agreed time between supervisors and students. The method of supervision was conducted through face to face discussion, question and answer. Students having intrinsically high motivation would have more frequencies of discussions with their supervisors but those of lack motivation would rarely see their supervisors. The time length of supervision varied from 20 to 30 minutes depending feedback corrections and student understanding. The supervisors have already fulfilled their competencies of supervising the final projects, but surely they requested longer duration since many of whom were busy and the number of supervisees was high (10 students). Students' boredom appeared when they had to wait for their turn of supervision or due to the supervisor's activity. In addition, based on interviews and observations after analyzing the data, the following findings could be elaborated as follows:

(a) The final project writing was often hampered by disagreement in determining research topics between the two supervisors, advisory committee and supervisor, supervisor and the student.

(b) The agreed supervision schedule sometimes changed due to unexpected reasons resulting in delay of supervision.

(c) One-to-one supervision enabled students to have deeper discussion with the supervisor.

This is in accordance with supervisors and students comments who stated that:

"There is no specific timetable for supervision; the supervisors allocate some of their time to communicate with the students. The method used debriefing discussion in which the students could raise any problems encountered. The Supervisor and the students are often involved in discussion to provide input ". (Students I, July 24, 2012). "The method used face-to-face, one supervisor and one student enabled the students to have deep talk. Prior to the supervision, the student had to submit the paper and then decided on the schedule of supervision. Supervision provided feedback, revision, and opportunity to express what the project would like to be. Schedule for supervision was set by agreement with the length of supervision ranges from 20 to 30 minutes. The supervisor has the capability of supervising but lack of time. "(Student J, August 9, 2012). While the supervisor said that: "There was no fixed schedule but they can meet at set up time through telephone or other 
The Analysis and Strategy on Final Project Completion (TA) by Midwifery Students of Health ..

social media. The method used was question and answer. Sometimes it takes about 90 minutes for three students"(Lecturer F, August 13, 2012)."Prior to the supervision the students are advised to submit their paper and decided the time of supervision. The methods used are discussions and assignments "(Lecturer G, August 14, 2012). Based on observations made during the process of supervision, discussion and individual counseling according to each topic, some students looked creepy while waiting for their turn for supervision.

The ability of the students in preparing the final project is strongly influenced by their prior knowledge in conduct of research. In this case it is found that the students' prior knowledge in conduct of research relatively poor. Their knowledge in conduct of research increases, but it is not sufficient enough to help them to write their final project. They still encounter some problems in chapter to chapter writing.

In determining research topics, the students stress on the title instead of observing the phenomena that exist resulting in students having difficulty in writing the background of research. Chapter one is crucial in terms of getting on their writing which will impact on the next chapter. This is consistent with the response of both lecturers and students who stated that: "Some students have their prior knowledge in conduct of research, while most of whom have not." (Lecturer F, August 13, 2012). "At the beginning of the supervision most students do not have any knowledge in conduct of research, although some of whom are ready with the reference" (Lecturer G, August 14, 2012). "In terms of students' skill in conduct of research it is very personal. Some students are fairly good in conduct of research but some others perform as if they had never received research methodologies. "(Lecturer H, August 15, 2012)."Students are always ready to receive materials of research methodology, but their prior knowledge is very limited, so in determining the research problem they still experience difficulties. The title is not derived from studying the phenomenon but more from the spontaneity of ideas and thoughts. "(Lecturer D, 9 September 2012).

It is also in accordance with the students' statements as follows:"I am confident with the ability to draw up the final project; I think the given framework in conduct of research has been sufficient to work on the paper, only the chapter by chapter practice should be given more. "(Student I, July 24, 2012). "I am sure I have already understood how to work on my research, but it would be better to have chapter to chapter based learning in Research Methodology Class. "(Student J, August 9, 2012)." I'm not sure yet if I have mastered the theory. I definitely need supervision. Any subject related to writing a scientific paper should be given more priority."(Student K, August 9, 2012). In addition from the documentation on the score sheet of the Research Methodology Course, 92 students got A (77\%), B (23\%), and no student got C. In conclusion the cognitive ability of students on Research Methodology is excellent.

\section{Discussion}

Efforts are being made to improve the students' skill on writing their final project and complete their study on the stipulated duration. This study is intended to achieve the mentioned goal through policy analysis using empirical and normative approach. The result is expected to be able to change the ongoing completion delay of students' final project. A SWOT analysis of strengths, weaknesses, opportunities and threats was firstly administered to find out sources of problems and their solutions. The optimal strategy obtained can be used as a reference for improvement in the completion of the students' final project on the sixth semester.

\section{SWOT analysis findings of the students' final project in Midwifery Diploma Program Health Polytechnic of Malang}

(a) Strengths:

(1) The availability of National Vocational Curriculum of Midwifery 2002, The National Competence Standard of The Indonesian Midwifery, and Syllabus of Midwifery Diploma Program

(2) The availability of Student handbook of final project writing for midwifery diploma program

(3) The students have taken Research Methodology Course

(4) Syllabus and lesson plan have been made up prior to Research Methodology Course

(5) The process of students' final project writing is coordinated by a special committee formed in semester V

(6) The supervisors' educational background of master degree

(7) The skill of lecturers and students in conduct of research

(8) High motivation, patience and perseverance of students and lecturers

(9) Intensive communication between the first and the second supervisors

(10) The skilled supervisors upon the content of the students' research

(11) An adequate library

(12) The allotted time provided by the supervisors

(b) Weaknesses:

(1) No formal supervision schedule, only informal agreement between the supervisor and the student

(2) The difficulty of arranging supervision due to supervisors' limited time

(3) Limited time of supervision 
The Analysis and Strategy on Final Project Completion (TA) by Midwifery Students of Health ..

(4) Lack of cooperation and communication between the first and the second supervisors

(5) Lack of respect of supervisor to student

(6) Less motivated students tend to hold supervision

(7) Unrecorded mobile phone numbers of the supervised students by supervisors

(8) Lack of cooperation between Research Methodology Course team and students' final project committee.

(c) Opportunities/ courage to change:

(1) Setting formal supervision schedule of students' final project writing,

(2) Varying teaching techniques and practices of Research Methodology Course,

(3) Offering Research Methodology Course at semester IV,

(4) Administering the final project committee and Research Methodology Course at the same period,

(5) Restricting lecturers giving lecture outside of of the Health Polytechnic of Malang,

(6) Synergizing perception among supervisors,

(7) Clarity of information of the sender in mobile phone communication bases,

(8) Adding up to date books in the Library.

(d) Threats / constraints / challenges:

(1) The polytechnic academic activities including in the Midwifery Diploma Program such as workshops, meetings, out of town tasks which involve the lecturers,

(2) As many midwifery diploma program established, lecturers of Health Polytechnic of Malang provides extra teaching services to other midwifery diploma program in needs, as the results the allotted time for supervision is definitely not optimal,

(3) Completion of the administration concerning with research site licensing.

\section{Timely Completion Strategy of Final Project of Students of Sixth Semester}

Based on the findings and analysis, further discussions about timely completion strategy will be directed to the following interrelated aspects such as: the implementation of the curriculum, process supervision, and students' skill in conduct of research.

(a) Implementation of curriculum,

In Midwifery Curriculum of 2002 issued by the Ministry of Health of the Republic of Indonesia, students' final project is worth 3 credits. The application should be systematically and sustainably planned. Newman states that planning is determining what to do. Planning cycle contains comprehensive decision and explanations of purpose, determination of policy, program determination, method determination and determination of certain procedures and activities based on the daily schedule (Majid, 2007). Planning must be systematic beginning from making the syllabus. Syllabus is a set of plans and arrangements of learning activities, classroom management and assessment of learning outcomes (Majid, 2007). Syllabus answers component of what competencies will be developed in the students, how to develop it and how the teacher knows that the students have already internalized the competence. Basing upon those theories, the following applications of the curriculum should necessarily be reviewed: (1) the standard competence of Research Methodology Course, (2) Research Methodology as the prerequisite course to take final project is given in the fifth semester, (3) the committee of students' final project writing formed at the beginning of the fifth semester immediately draws up lists of supervisors and students, (4) a special meeting is aimed at synergizing perception between Research Methodology team and supervisors, (5) In the fifth semester students have already started drafting a proposal of the final project as part of the tasks in Research Methodology Course, (6) the task of making a proposal is expected to be approved by the supervisor to be proceeded for the final project, (7) Synchronization between the students' final project writing and Clinical Practice of Midwifery (PKK) by choosing the nearby location to enable students to do supervision and clinical practice at the same time.

\section{(b) Supervision Process of the Final Project}

The process of supervision begins from well-prepared plan supported with good communication aimed at creating well supervisor-student relationship and capability of strategy development by students on the final project writing. Management of learning is a process guiding learners to organize interaction of learners and educators as well as learning resources in a learning environment. According to Dunkin and Biddle (in Majid, 2007) there are four variables of interaction in the learning process, namely: 1) educators as the sign variable; 2 ) learners as the context variable; 3) the process variables; and 4) the product variable product. The implementation of supervision should be planned. The schedule and supervision procedures should be obeyed. Step by step supervision and reference readings should be fostered. The previous stages are then described as follows (1) a target date set from the beginning of supervision (2) face to face supervision and reference reading assignments, (3) group supervision applied to some students taking the same area of research, (4) individual supervision specific case, (5) adequate time allotted for supervision, (6) obedience upon the supervision schedule jointly agreed between students and supervisors, (7) agreement of both parties students and supervisors 
The Analysis and Strategy on Final Project Completion (TA) by Midwifery Students of Health ..

in terms of delayed supervision, (8) both supervisors should share same understanding for the sake of timely completion of the students' final project, (9) adjusting the number of supervisees according to the availability of time of supervision, (10) Increasing the skill of the lecturers in Research Methodology and Biostatistics.

\section{(c) Preparation of Students' Skill in Conduct of Research}

Dunkin and Biddle (in Majid, 2007) state that in the learning process, learner as the context variable is part of the four variables of interaction. Students' skill should be fostered gradually through the following stages: (1) the objective of Research Methodology Course should be emphasized on chapter to chapter writing practice bases, (2) writing a proposal of research should be the end product of the course by providing adequate feedback or input, (3) keeping and maintain motivation in dealing with problem and solution, (4) assigning more reading on related books and previous research.

The following chart illustrates the flow of the completion strategy of scientific papers on schedule.

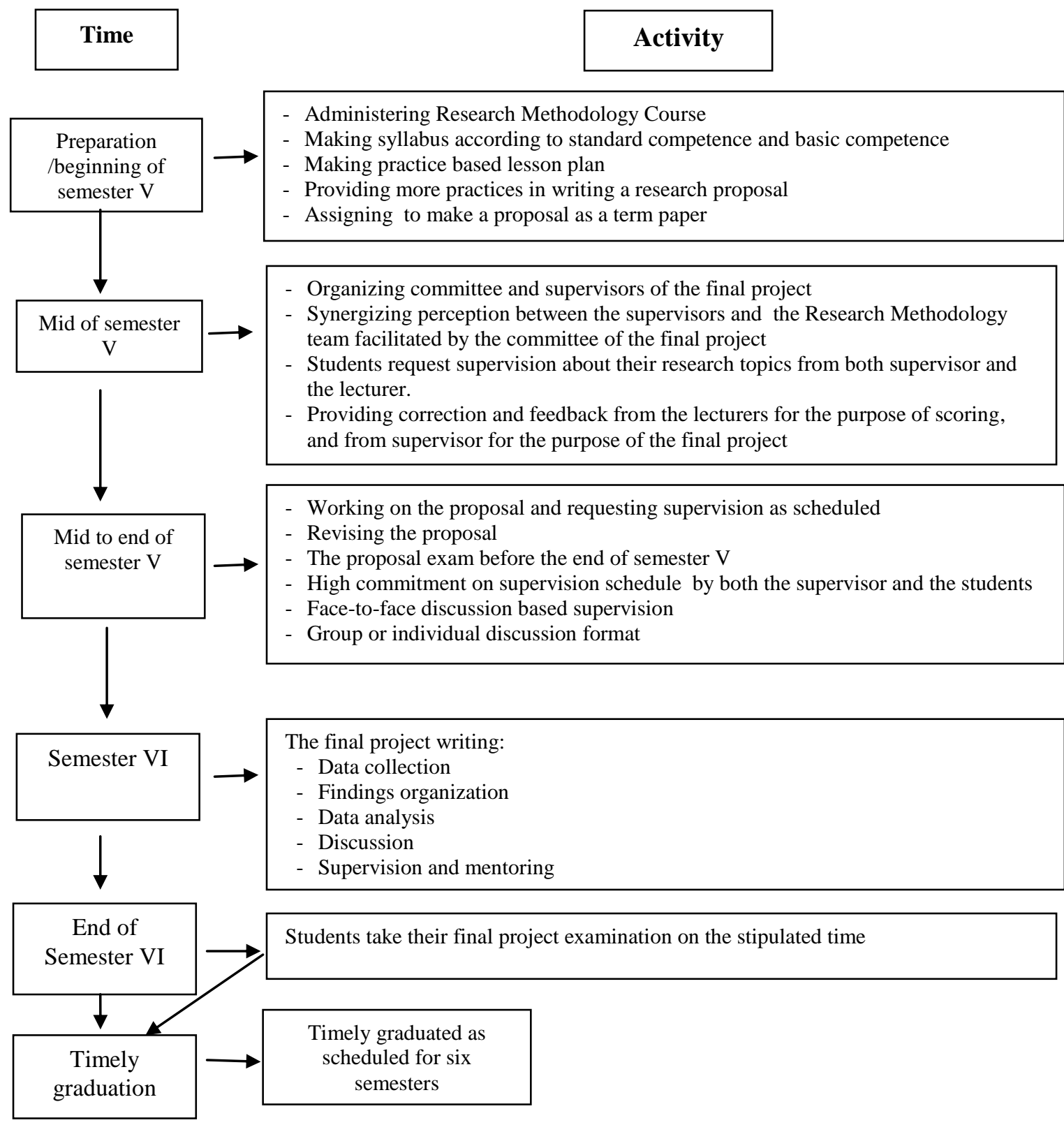

Figure (2) Timely Strategy Completion of Final Project 


\section{Conclusions and Suggestions}

\section{Conclusion}

As has been discussed, the conclusions of this study can be formulated as follows:

(A) The description of the implementation of students' final project at Midwifery Diploma Program of Health Polytechnic of Malang in the 2012/2013 School Year as follows:

(1) The implementation of the curriculum related to the preparation of the students' final project started from students taking Research Methodology Course (2 credits) at semester V. Since the method used in the Research Methodology class is not practice based and the proposal has already been assigned in the middle of semester the proposal has already begun in the mid-term $\mathrm{V}$, the students still find difficulty in working on their final project in semester VI.

(2) Supervision schedule is not formally set as a result it is difficult to predict the progress of final project completion. Due to the flexibility of supervision which depends a lot on the supervisors' availability of time resulting students who works harder on their paper will request more often supervision, however for those who lack of motivation tend slow down their work and supervision. The length of supervision varies from 20-30 minutes depending on the corrections. Face to face discussion supervision enables the students to have deeper understanding of what they are working with.

(3) Students' prior knowledge in conduct of research is very limited. After taking Research Methodology class, the students acquire better understanding although it is not helpful enough to work with their final project in sixth semester. They still experience difficulties in determining some issues such as: deciding the title. Too much theoretical framework and less practice caused disadvantages to students who need chapter to chapter practice.

(B) Timely completion strategy on students' final project:

(1) Implementation of the curriculum.

The standards and basic competencies of Research Methodology Course should be reviewed before preparing a syllabus in semester $\mathrm{V}$. the lesson plans should emphasize more on practice especially chapter per chapter bases. The preparation of the students' final project and determining the supervising committee should be conducted at midterm V in order to facilitate the task of the students taking Research Methodology Course for the purpose of their final project,

(2) Supervision Process.

Fixed timetable should be made and used for guidance of progress by both lecturers and students. Supervision on research topics should be conducted to the lecturers and tutors. Face to face discussion based and extra reading assignment should be empowered for students' deeper understanding. Getting the same perception between the supervisors and the teaching team of Research Methodology Course should be facilitated by the students' final project committee,

(3) Preparing students' skill in conduct of research.

Chapter to chapter practice based should be emphasized in Research Methodology class. Students should be assigned the task of making up proposals and followed up with intensive feedback or input. Keeping and maintaining students' motivation when finding problems should be put in priority. At last assigning more exercise and reading more books and previous research should be in the activity.

\section{Suggestions}

(A) For education practitioners; the results of the research can be useful as reference to evaluate and improve the supervision process in the completion of students' final project on time,

(B) For further researcher; the future potential research is to test the effectiveness, efficiency and flexibility of the completion strategy of the students' final project.

\section{References}

[1]. Ali Lukman. 1994. Kamus Besar Bahasa Indonesia. Jakarta: Departemen Pendidikan dan Kebudayaan.

[2]. Bogdan, H.R \& Biklen, S.K. 1992. Qualitative Research For Education: An Introduction to Theory and Methods. New York: The Macmilian Publishing Company.

[3]. Danim,Sudarwan. 2000. Pengantar Studi penelitian Kebijakan. Jakarta: Bumi Aksara

[4]. Departemen Kesehatan RI, 2002, Kurikulum Nasional Pendidikan Diploma III Kebidanan, Jakarta. 
The Analysis and Strategy on Final Project Completion (TA) by Midwifery Students of Health ..

[5]. Departemen kesehatan RI.2006. Pedoman Penilaian Pencapaian Kompetensi Pendidikan Tenaga Kesehatan. Jakarta: Badan PPSDM-Departemen Kesehatan RI

[6]. Departemen kesehatan RI.2006. Panduan Akademik Politeknik Kesehatan Malang. Malang: Politeknik Kesehatan Malang

[7]. Miles, M.B \& Huberman, A.M. 1994. Qualitative Data Analysis. Second Edition. California: SAGE Publications.

[8]. Moleong, L.J.(Ed). 1995. Metodologi Penelitian Kualitatif. Bandung: Rosdakarya.

[9]. Mulyasa, E. 2002. Kurikulum Berbasis Kompetensi, Konsep, Karakteristik dan Implementasi. Bandung: Rosda Karya.

[10]. Politeknik Kesehatan Kemenkes Malang. 2009. Pedoman Penyusunan Karya Tulis Ilmiah Program DIII Kesehatan Di Lingkungan Poltekkes Kemenkes Malang. Malang.

[11]. Punaji Setyosari. 2005. Rancangan Pembelajaran. Malang: Universitas Malang Press.

[12]. Sugiyono. 2007. Metode Penelitian Kuantitatif Kualitatif Dan R \& D. Bandung: ALFABETA

[13]. Zuriah Nurul. 2006. Metodologi Penelitian Sosial Dan Pendidikan. Jakarta: Bumi Aksara. 